\title{
PENINGKATAN LITERASI DIGITAL MELALUI PEMBUATAN PANDUAN PENULISAN ESSAY BAGI SISWA SMA DI MASA PANDEMI COVID-19
}

\author{
Deasy Olivia ${ }^{1}$, Hendra Mayatopani ${ }^{2}$, Farel Ivander Daviano Siwy ${ }^{3}$ \\ ${ }^{1}$ Program Studi Perencanaan Wilayah dan Kota, Universitas Pradita \\ ${ }^{2}$ Program Studi Sistem Informasi, Universitas Pradita \\ ${ }^{3}$ Program Studi Sistem Informasi, Universitas Pradita
}

deasy.olivia@pradita.ac.id , hendra.mayatopani@pradita.ac.id, farel.ivander@student.pradita.ac.id

\begin{abstract}
Abstrak
Perkembangan teknologi dan era revolusi industri 4.0 memberikan dampak yang signifikan terhadap percepatan informasi. Pandemi Covid-19 membuat transformasi digital dalam pembaharuan informasi dan ilmu pengetahuan. Namun, potensi ini belum dimanfaatkan dengan baik oleh siswa di Indonesia. Hal ini terlihat masih rendahnya kemampuan literasi siswa untuk mengolah dan menganalisis informasi yang berkembang untuk diolah menjadi sebuah karya ilmiah yang menarik dan berkualitas. Kurangnya pemahaman tentang cara mengolah dan menganalisis informasi dalam bentuk tulisan menjadi salah satu faktor yang menyebabkan rendahnya kemampuan literasi siswa. Adanya fenomena ini memunculkan ide untuk membuat panduan penulisan essay bagi siswa khususnya siswa SMA. Kegiatan ini bertujuan untuk mengedukasi dan meningkatkan kemampuan literasi digital melalui penulisan essay dan pengembagan kreatifitas siswa dalam karya tulis essay. Adanya panduan ini diharapkan dapat meningkatkan dan memotivasi minat baca dan menulis siswa untuk menganalisis tema-tema yang menarik dan menggali ide kreatif untuk merespons pandemi Covid-19. Kegiatan ini dilaksanakan dengan membuat panduan penulisan essay dan memberikan edukasi secara daring kepada siswa SMA dari beberapa kota di Indonesia. Hasil kegiatan ini berupa panduan penulisan essay dan beberapa hasil karya penulisan essay yang dilakukan oleh siswa menggunakan panduan penulisan essay yang telah dijelaskan kepada siswa SMA.
\end{abstract}

Kata Kunci : kemampuan, literasi digital, panduan, penulisan essay, siswa SMA

\section{PENDAHULUAN}

Perkembangan teknologi dan era revolusi industri 4.0 memberikan dampak yang signifikan terhadap percepatan informasi. Adanya teknologi kita dapat memperoleh informasi dengan cepat dan melihat jendela dunia melalui literasi. Namun, perkembangan teknologi yang semakin cepat didukung kemudahan dalam mendapatkan informasi tidak berbanding lurus dengan peningkatan kemampuan digital anak-anak dan kaum muda di Indonesia. Berdasarkan data survey yang dilakukan oleh Program for International Student Assessment
(PISA) menunjukkan bahwa tingkat literasi Indonesia berada di ranking ke 62 diantara 70 negara.Hal ini menunjukkan bahwa tingkat literasi Indonesia masih tergolong rendah jika dibandingkan dengan negara lain (Larasati dalam https://perpustakaan.kemendagri.go.id/?p=4661, 23 Maret 2021).

Pandemi Covid-19 yang terjadi di Indonesia turut mempengaruhi penurunan kemampuan literasi anak-anak Indonesia. Adanya pembatasan dalam aktivitas mengharuskan seluruh kegiatan dilakukan secara daring dan mandiri. Hal ini turut membuat kemampuan literasi anak Indonesia semakin 
menurun karena kurangnya pemahaman literasi dan kemampuan untuk menganalisis sebuah informasi yang diperoleh baik melalui media cetak maupun media online.

Siswa Sekolah Menengah Atas (SMA) merupakan generasi milenial yang sangat aktif dalam meggunakan teknologi dalam melaksanakan proses pembelajaran maupun mengaktualisasikan diri, khususnya di masa pademi Covid-19. Adanya potensi yang dimiliki siswa SMA ini sebagai generasi milenial perlu diarahkan ke dalam bentuk kegiatan yang lebih bermanfaat untuk meningkatkan kemampuan literasi digital dan kemampuan berpikir kritis melalui kegiatan penulisan essay. Kegiatan menulis essay tidak hanya sekedar melatih kemampuan menulis dan berpikir, akan tetapi dapat menjadi wadah bagi siswa SMA dalam mengungkapkan ide dan gagasan serta mentransformasikan ilmu pengetahuan secara tepat berbasis kaidah-kaidah penulisan ilmiah. Dengan demikian, sebagai bentuk kegiatan pengabdian kepada masyarakat ini dilakukan pembuatan panduan penulisan essay yang sesuai dengan kaidah ilmiah namun tetap memperhatikan tingkat kemampuan berpikir bagi siswa SMA.

Tujuan kegiatan pengabdian kepada masyarakat ini adalah untuk mengeksplor ide dan gagasan serta kreativitas siswa SMA dalam mengungkapkan ide dan gagasan terkait dengan topik yang sedang hangat terkait dengan peran Bitcoin sebagai alat tukar serta memberikan pemahaman tentang cara menulis essay yang baik dan benar sesuai dengan kaidah ilmiah dan meningkatkan budaya membaca siswa melalui literasi digital yang positif dengan informasi yang bermanfaat. Dengan adanya kegiatan ini diharapkan siswa SMA dapat belajar untuk mengaktualisasi diri melalui ide dan gagasan positif yang dituangkan dalam bentuk tulisan serta menjadikan penulisan essay sebagai sebuah budaya baru untuk menciptakan ekosistem ilmiah bagi kaum milenial ini.

\section{Tinjauan Pustaka}

\section{Tinjauan tentang Literasi}

Literasi merupakan kemampuan seseorang dalam memahami, menggunakan dan merefleksikan bacaan tertulis untuk mencapai tujuan sesuai keperluan, mengembangkan pengetahuan dan potensi, serta berpartisipasi dalam masyarakat (Harsiyati, 2018).

Menurut Wells dalam Febrianti (2017) literasi memiliki 4 (empat) tingkatan yaitu sebagai berikut:

1. Performative: yaitu kemampuan membaca dan menulis;

2. Functional: yaitu menunjukkan kemampuan menggunakan bahasa untuk keperluan hidup atau skill for survival seperti membaca manual, mengisi formulir, dan sebagainya;

3. Informational: yaitu menunjukkan kemampuan untuk mengakses pengetahuan;

4. Epistemic: yaitu menunjukkan kemampuan mentransformasikan pengetahuan.

Literasi digital secara sederhana dapat dimaknai sebagai kemampuan pengguna media digital dalam memperoleh, mengolah, dan menyampaikan informasi. Melalui literasi digital diharapkan warga negara sebagai pengguna media digital tidak serta merta mengkonsumsi dan menyebarkan infomrasi, namun dilakukan juga pemilahan dan pemilihan informasi yang faktual dan akurat (Pradana, 2018).

Menurut Wijonarko (2020), literasi memiliki beberapa manfaat yaitu sebagai berikut:

a. Menambah pembendaharaan kata "kosa kata" seseorang.

b. Mengoptimalkan kinerja otak karena sering digunakan untuk kegiatan membaca dan menulis.

c. Mendapat berbagai wawasan dan informasi baru.

d. Kemampuan interpersonal seseorang akan semakin baik.

e. Kemampuan memahami suatu informasi akan semakin meningkat.

f. Meningkatkan kemampuan verbal seseorang.

g. Meningkatkan kemampuan analisis dan berpikir seseorang.

h. Membantu meningkatkan daya fokus dan kemampuan konsentrasi seseorang.

i. Meningkatkan kemampuan seseorang dalam merangkai kata yang bermakna dan menulis. 


\section{Tinjauan tentang Essay}

\section{a. Pengertian Essay}

Essay merupakan karya tulis yang ditulis berdasarkan pandangan penulis terhadap suatu masalah, objek atau peristiwa yang akan ditulisnya. Esai bersifat pribadi karena penulisan esai disesuaikan dengan gaya penulisan penulisnya. Struktur esai terdiri dari (1) pendahuluan, (2) pembahasan, (3) kesimpulan (Lubis, 2017).

b. Pentingnya Kemampuan Menulis Essay Kemampuan menulis essay merupakan kemampuan yang penting dan strategis bagi siswa. Melalui penulisan essay dapat memberikan kontribusi positif bagi permasalahan yang terjadi di masyarakat dengan menuangkan ide dan gagasan dalam tulisan essay. Selain itu, menulis essay dapat menumbuhkan kemampuan berpikir kritis dan kreatif pada siswa tanpa menimbulkan tindakan anarkis maupun tindakan negatif (Lubis, 2017).

\section{c. Langkah-Langkah Menulis Essay}

Menurut Lubis (2017) langkah-langkah menulis essay adalah sebagai berikut:

1. Menentukan tema atau pembahasan

2. Membuat outline atau garis besar ide-ide yang akan kita bahas

3. Menuliskan pendapat penulis dengan kalimat yang singkat dan jelas

4. Menulis tubuh essay, memulai dengan memilah nilai-nilai penting yang akan dibahas, kemudian menulis subtema pembahasan

5. Membuat paragraf pertama yang sifatnya sebagai pendahuluan yang berisi alasan atau latar belakang alasan dan urgensi penulis mengambil topik dan menulis essay tersebut

6. Menulis kesimpulan.

\section{METODE}

Kegiatan pengabdian kepada masyarakat ini menggunakan metode sosialisasi dan pelatihan (workshop) secara daring yang dilakukan kepada siswa SMA yang ada di beberapa kota di Indonesia, yaitu:

a. SMA Mardi Yuana Bogor b. SMKS Kristen Immanuel Pontianak

c. SMA Markus Tangerang

d. SMKN 3 Tangerang

Tahap pelaksanaan kegiatan pengabdian kepada masyarakat ini adalah sebagai berikut:

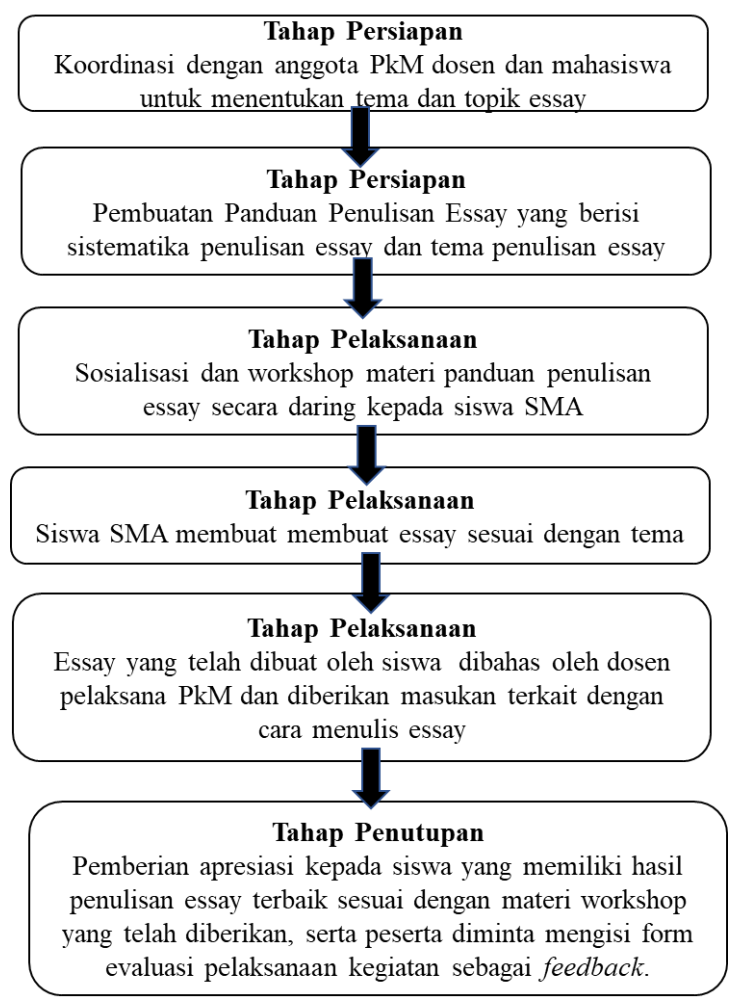

Gambar 1. Tahapan Kegiatan Pengabdian

kepada Masyarakat Pembuatan Panduan Penulisan

Essay bagi Siswa SMA

Sumber: Penulis (2021)

\section{HASIL DAN PEMBAHASAN}

Kegiatan pengabdian kepada masyarakat ini diawali dengan koordinasi bersama dengan anggota PkM dosen dan mahasiswa untuk menentukan tema dan topik essay. Kegiatan pengabdian kepada masyarakat ini merupakan kegiatan bersama antara dosen pelaksana PkM dengan mahasiswa pengurus Himpunan Mahasiswa Sistem Informasi (HIMSI) diawali pada 12 Desember 2021 dan dilanjutkan koordinasi untuk finalisasi tema dan panduan tata cara penulisan essay pada 23 Januari 2021. Rapat dilaksanakan bersama dengan mahasiswa HIMSI. 
Kegiatan berikutnya dilanjutkan dengan pembuatan panduan tata cara penulisan essay yang dikerjakan oleh Dosen pelaksana PkM yaitu Ibu Deasy Olivia dan Bapak Hendra Mayatopani yang menyusun panduan tata cara penulisan essay beserta indicator penilaian ketercapaian essay. Tujuannya untuk memberikan edukasi dan pemahaman kepada siswa SMA tentang cara menulis essay yang baik dan benar serta siswa dapat diberikan pemahaman kriteria essay yang baik harus memenuhi beberapa indicator. Kegiatan penulisan essay yang dilaksanakan pada 08 Februari 2021 ini memiliki tema 'Bisnis Milenial Bagi Kaum Milenial" dengan sub tema sebagai berikut:

a. Peluang Bitcoin sebagai alat tukar dan pembayaran di masa depan;

b. Legalitas transaksi bitcoin antarnegara

c. Pertumbuhan dan perkembangan bitcoin di Indonesia

d. Peluang investasi dan trading bitcoin

e. Inovasi teknologi dalam sistem keamanan bitcoin

Pembuatan panduan penulisan atau tata cara penulisan essay yang dibuat berisi tentang ketentuan dan sistematika penulisan essay mulai dari bagian pendahuluan, isi, dan penutup, serta tata cara penulisan sumber pustaka.

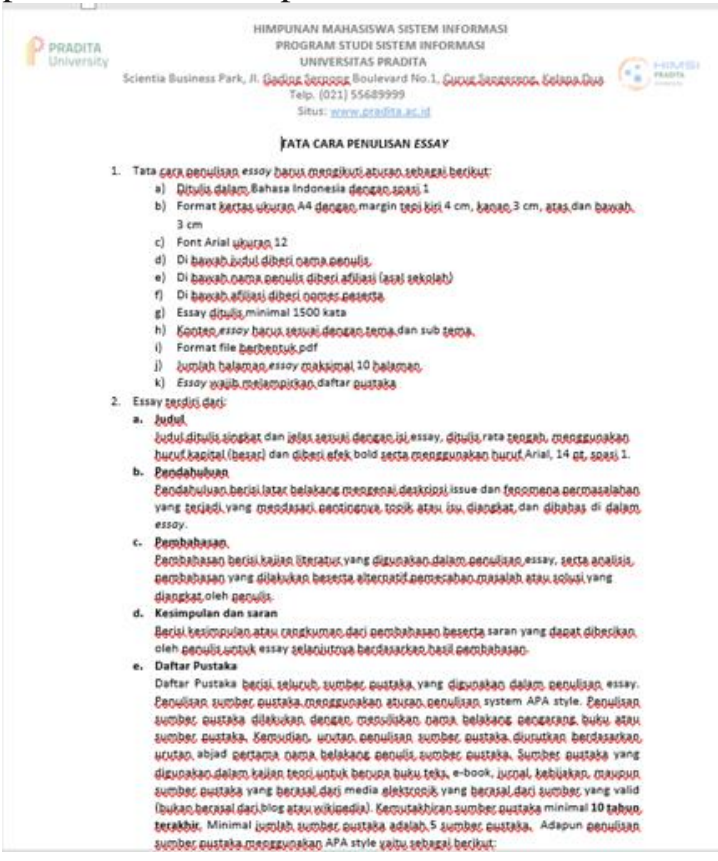

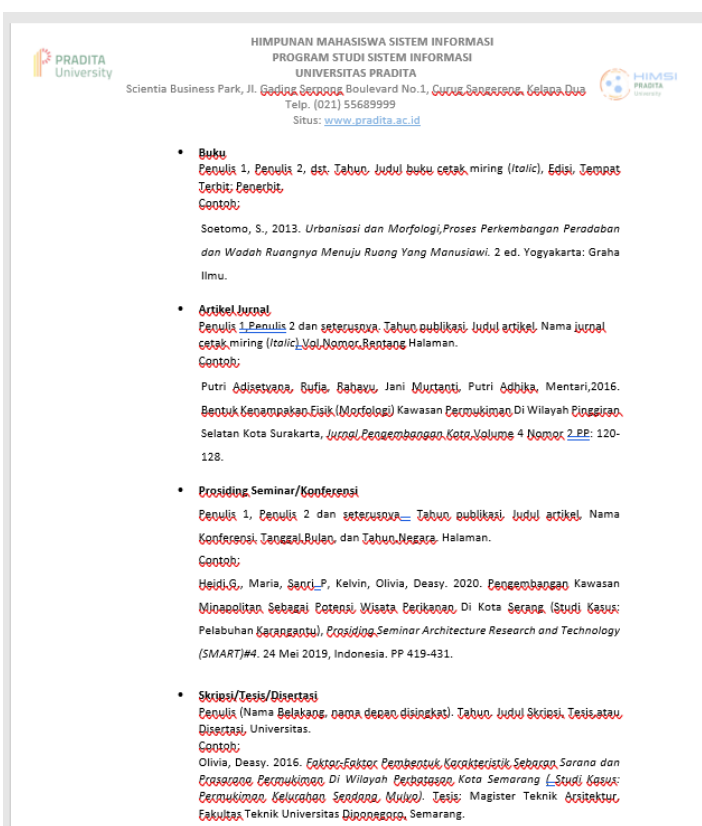

Gambar 2. Tampilan Panduan Tata Cara Penulisan Essay Sumber: Penulis (2021)

Selain panduan tata cara penulisan essay, dalam kegiatan ini juga dibuat indikator untuk memeriksa hasil penulisan essay yang akan dilaksanakan oleh siswa SMA setelah panduan ini disosialisasikan dan diberikan workshop. Indikator yang digunakan untuk menilai essay yang dibuat oleh siswa adalah sebagai berikut:

Tabel 1. Kriteria Penilaian Essay

\begin{tabular}{llc}
\hline No & \multicolumn{1}{c}{ Kriteria Penilaian } & Bobot $(\%)$ \\
\hline 1 & Kesesuaian Isi terhadap tema & 10 \\
2 & $\begin{array}{l}\text { Tinjauan Pustaka: } \\
\text { a.Relevansi } \\
\text { b.Kemutakhiran } \\
\text { c.Penyusunan daftar pustaka }\end{array}$ & 20 \\
3 & $\begin{array}{l}\text { Orisinalitas } \\
\text { Kedalaman pembahasan }\end{array}$ & 20 \\
\hline Jumlah & 50 \\
\hline
\end{tabular}


Tahapan selanjutnya ketika panduan tata cara penulisan essay sudah selesai, kegiatan dilanjutkan dengan melakukan sosialisasi dan workshop penulisan essay yang dilaksanakan pada 08 Februari 2021 secara daring. Penyampaian sosialisasi disampaikan oleh mahasiswa HIMSI dan pemaparan materi disampaikan oleh dosen pelaksana PkM yaitu Ibu Deasy Olivia.

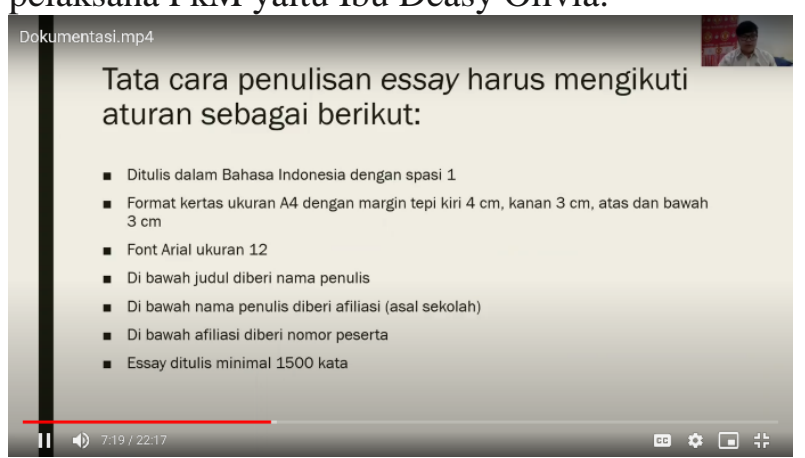

- Konten essay harus sesuai dengan tema dan sub tema

- Format file berbentuk pdf

- Jumlah halaman essay maksimal 10 halaman

- Essay wajib melampirkan daftar pustaka

Essay terdiri dari:

- Judul Judul ditulis singkat dan jelas sesuai dengan isi essay, ditulis rata tengah,
mengsunakan huruf kapital (besar) dan diberi efek bold serta menggunakan hurut Anial, 14 pt, spasi 1

- Pendahuluan

Pendahuluan berisi latar belakang mengenai deskripsi issue dan fenomena permasalahan yang terjadi yang mendasari pentingnya topik atau isu diangkat dan dibahas di dalam essay.
- Pembahasar

embahasan berisi kajian literatur yang digunakan dalam penulisan essay. serta analisis pembahasan yang dilakukikan besert
masalah atau solusi yang diangkat oleh penulis

- Kesimpulan dan saran Berisi kesimpulan atau rangkuman darl pembahasan beserta saran yang
dapat diberikan oleh penulis untuk essay selanjutrnya berdasarkan hasil
pembahasan.

Gambar 3. Penyampaian sosialisasi dan workshop tata cara penulisan essay bagi siswa SMA.

(a) Penyampaian materi oleh mahasiswa HIMSI, (b) penyampaian materi oleh dosen pelaksana $\mathrm{PkM}$

Sumber: penulis, 2021

Pelaksanaan kegiatan pengabdian kepada masyarakat dilanjutkan kembali dengan pembuatan essay yang dilaksanakan oleh peserta siswa SMA, didampingi oleh dosen pelaksana PkM dan mahasiswa HIMSI secara daring. Peserta diberikan dateline 2 minggu untuk menulis essay sesuai dengan tema workshop dan produk essay dikirimkan ke panitia HIMSI pada 22 Februari 2021 untuk selanjutnya akan di review oleh reviewer dari dosen pelaksana PkM. Kemudian pada 10 Maret 2021, peserta diundang kembali untuk mempresentasikan hasil penulisan essay serta diberikan masukan serta diskusi bersama dengan tim reviewer terkait dengan hasil penulisan dan peserta juga mendapat masukan dari tim reviewer mengenai isi essay yang baik. Dalam penulisan essay ini, siswa menjalankan tingkatan essay yaitu sebagai berikut:

1. Performative: yaitu kemampuan membaca dan menulis. Tingkatan performative ini didapat ketika siswa belajar menulis essay sesuai dengan tema dan sistematika penulisan;

2. Functional: yaitu menunjukkan kemampuan menggunakan bahasa. Tingkat kemampuan ini dilakukan dalam penulisan essay yakni siswa belajar untuk menulis menggunakan bahasa Indonesia yang baik dan benar sesuai dengan tema penulisan essay; 
3. Informational: yaitu menunjukkan kemampuan untuk mengakses pengetahuan. Kemampuan ini diperoleh siswa dalam penulisan essay, yakni ketika siswa harus mencari sumber informasi dan teori yang berkaitan dengan judul essay yang ditulis sesuai dengan tema penulisan essay. Dalam kemampuan ini siswa belajar untuk mengkases informasi yang tepat guna sesuai

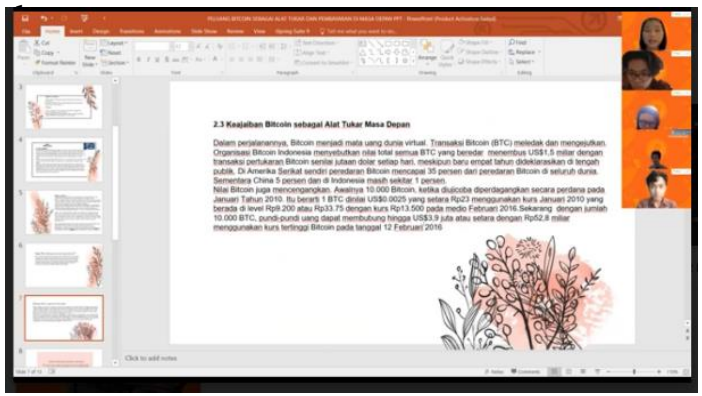

$\mathrm{m}$

a yang akan dibahas, serta belajar mengungkapkan ide dan gagasan kreatif melalui tulisan berbasis data informasi yang tepat dari sumber yang benar.

Gambar 4. Presentasi penulisan essay dalam menyajikan informasi tentang bitcoin oleh peserta

Sumber: penulis, 2021

4. Epistemic: yaitu menunjukkan kemampuan mentransformasikan pengetahuan. Kemampuan pada tingkatan ini ditunjukkan oleh siswa dalam menulis essay ketika di tahap pembahasan. Dengan adanya kegiatan ini, siswa dapat menambah kosa kata baru mengenai tema dan judul penulisan tentang bitcoin serta mendapatkan masukan mengenai cara untuk memperdalam analisa dan pembahasan untuk mentransformasikan pengetahuan. Dari penulisan essay ini siswa tidak hanya sekedar mengumpulkan informasi tentang bitcoin, akan tetapi mereka belajar untuk menganalisis data dan menyimpulkan untuk menjadi sebuah temuan informasi baru terkait dengan bitcoin.

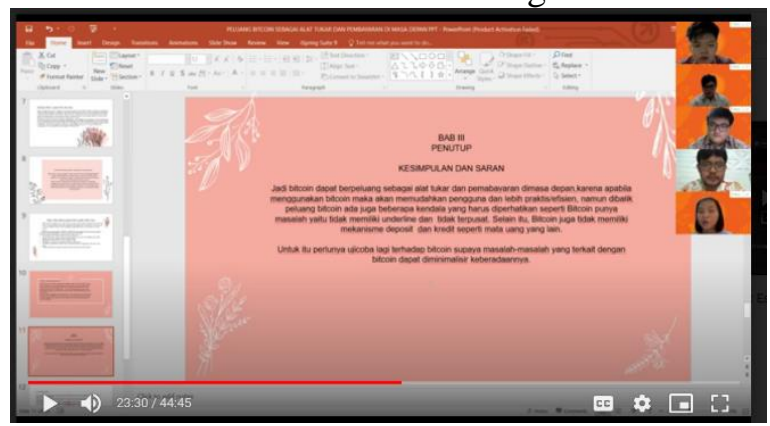

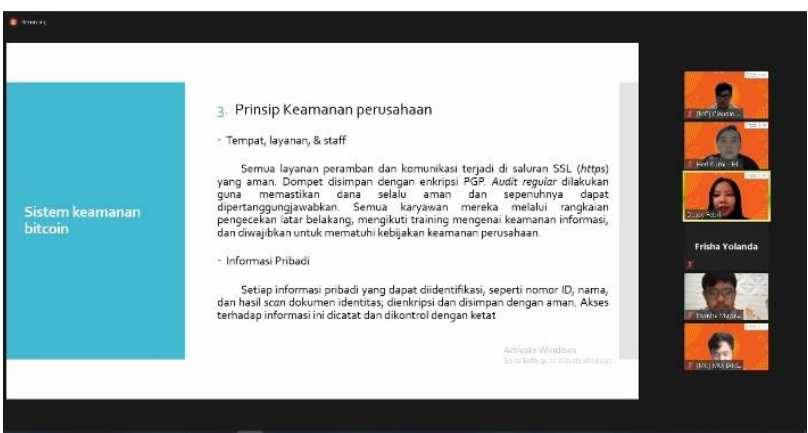

Gambar 5. Presentasi penulisan essay dalam menerapkan kemampuan epistemic dalam tentang bitcoin oleh peserta Sumber: penulis, 2021

Pelaksanaan kegiatan pengabdian kepada masyarakat pada sesi selanjutnya adalah sesi penutup yang dilakukan berupa penyampaian apresiasi terhadap produk essay terbaik yang telah ditulis oleh siswa serta dilakukan sesi foto bersama.

Gambar 6. Sesi foto bersama penutupan pelaksanaan presentasi hasil penulisan essay siswa SMA

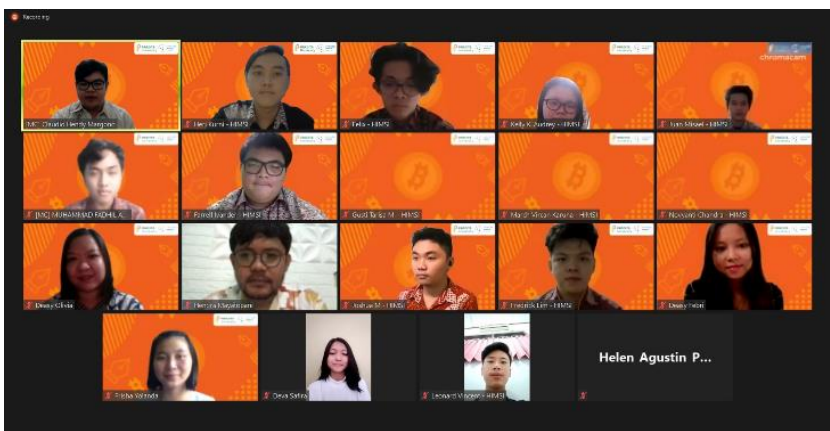

Sumber: penulis, 2021

\section{KESIMPULAN}

Berdasarkan kegiatan pengabdian kepada masyarakat yang telah dilakukan mengenai peningkatan literasi digital melalui pembuatan panduan penulisan essay bagi siswa SMA di masa pandemic Covid-19 dapat disimpulkan bahwa dengan kegiatan penulisan essay ini siswa tidak hanya sekedar mendapatkan informasi tentang tata cara menulis essay, tetapi juga mendapat 
pengalaman baru dan menulis essay dapat menjadi media untuk meningkatkan kreatifitas dan mengeksplor ide dan gagasan siswa SMA sebagai kaum milenial dalam memberikan respons terhadap perkembangan informasi dan teknologi khususnya bitcoin sebagai alat tukar. Adanya penulisan essay dapat menstimulasi siswa untuk mengaktualisasi diri dengan cara yang tepat melalui tulisan. Selain itu, menulis essay juga dapat meningkatkan kemampuan berpikir kritis dan melatih siswa SMA untuk mentransformasi pengetahuan berdasarkan sumber yang benar dan belajar untuk menganalisis informasi yang diperoleh sebelum dikemukakan baik dalam secara lisan maupun tulisan. Adanya pandemic Covid-19 tidak menghalangi siswa SMA sebagai kaum milenial untuk tetap aktif dalam mengungkapkan ide-ide kreatif dalam merespons perkembangan informasi khususnya tentang Bitcoin. Dengan demikian, untuk keberlanjutan kegiatan pengabdian kepada masyarakat selanjutnya, dapat ditingkatkan lagi tidak hanya sekedar menulis essay tetapi juga ditambah dengan pelatihan menulis karya ilmiah dan membuat infografis data yang tepat guna dan siswa diberikan kesempatan untuk mempresentasikan hasil karya ilmiah yang telah dibuat dan diberikan apresiasi berupa publikasi di jurnal nasional.

\section{UCAPAN TERIMAKASIH}

Penulis mengucapkan terima kasih kepada Universitas Pradita, khususnya Program Studi Sistem Informasi dan Program Studi Perencanaan Wilayah dan Kota, serta mahasiswa Himpunan Mahasiswa Sistem Informasi (HIMSI) yang telah memberikan kepercayaan bagi penulis dan berintegrasi dalam kegiatan pengabdian kepada masyarakat ini.

\section{REFERENSI}

Febrianti Yola, Lifia, Irianto Oviolanda, Putri. (2017). Pentingnya Penguasaan Literasi Bagi Generasi Muda Dalam Menghadapi MEA, The $1^{\text {st }}$ Education and Language International Conference Proceedings Center for International Language Development of Unissula.
Harsiati, Titik. (2018). Karakteristik Soal Literasi Membaca Pada Program PISA, Jurnal LITERA, Volume 17, No.1.

Lubis Wisuda, Sandi Silvia. (2017). Ketrampilan Menulis Essai Dalam Pembentukan Berpikir Kritis Mahasiswa Prodi PGIM UIN ARRANIRY Banda Aceh, Jurnal Pendidikan PIONIR Volume 6, No. 2

Pradana, Yudha. (2018). Atribusi Kewargaan Dalam Literasi Digital, Untirta Civic Education Journal (UCEJ), Vol. 2 No. 2

Utami, Dyah Larasati.(2021)." Tingkat Literasi Indonesia di Dunia Rendah, Ranking 62 Dari 70

Negara". https://perpustakaan.kemendagri.go.id/?p=46 61 . 23 Maret 2021

Wijonarko, Sumiati, Eti. (2020). Manfaat Literasi Digital Bagi Masyarakat dan Sektor Pendidikan Pada Saat Pandemi Covid-19, Buletin Perpustakaan Universitas Islam Indonesia, 3(2), PP 65-80. 